Article

\title{
Effect of Severe Plastic Deformation, through Equal-Channel Angular Press Processing, on the Electrochemical Behavior of A15083 Alloy
}

\author{
Asiful H. Seikh ${ }^{1, *(D)}$, Muneer Baig ${ }^{2}$ and Ateekh Ur Rehman ${ }^{3}$ (i) \\ 1 Centre of Excellence for Research in Engineering Materials, Deanship of Scientific Research, \\ King Saud University, P.O. Box 800, Riyadh 11421, Saudi Arabia \\ 2 Engineering Management Department, College of Engineering, P.O. Box 66833, Prince Sultan University, \\ Riyadh 11586, Saudi Arabia; mbaig@psu.edu.sa \\ 3 Department of Industrial Engineering, College of Engineering, King Saud University, P.O. Box 800, \\ Riyadh 11421, Saudi Arabia; arehman@ksu.edu.sa \\ * Correspondence: aseikh@ksu.edu.sa
}

Received: 15 September 2020; Accepted: 29 October 2020; Published: 3 November 2020

\begin{abstract}
In this study, Al5083 alloy was deformed through equal-channel angular pressing (ECAP) up to three passes. The ECAP was conducted at room temperature in a mold using route $C$. The microstructure evolution was investigated under optical microscopic observations. The grain size was measured using ImageJ software. Grain refinement from $145 \mu \mathrm{M}$ (as received) to $37 \mu \mathrm{M}$ (after third pass) was observed due to ECAP. The potentiodynamic polarization of the Al5083 alloy was obtained from a 3.5\% sodium chloride solution. Electrochemical impedance spectroscopy was performed in the sodium chloride solution to study the alloy's surface properties. Scanning electron microscopy and Raman spectroscopy were conducted after obtaining the corrosion performance. As a result, we found that ECAP processing leads to the grain refinement of the alloy, which causes a detrimental effect on the corrosion resistance property.
\end{abstract}

Keywords: aluminum alloy 5083; ECAP; potentiodynamic polarization; electrochemical impedance spectroscopy; Raman spectroscopy

\section{Introduction}

Aluminum alloys are extensively considered for application in aeronautic vehicle structures, because they are lightweight and have excellent properties [1-4]. The most widely used material in engineering applications is aluminum and its alloy. The ultra-fine-grained (UFG) Al5083 alloy has high strength, good weldability, and corrosion resistance; hence, there is huge demand for it and is has applications in different vehicle body parts, as well as plates used for making armor, ship bodies, and so on. Accordingly, researchers have been doing extensive research to develop UFG materials by applying severe plastic deformation (SPD). On the contrary, the corrosion behaviour of aluminium alloys, processed by equal-channel angular pressing (ECAP), is still under study. Aluminium alloys are susceptible to all corrosion forms, but pitting is the most important one. Generally, pitting occurs when the passive film around second phase particles, scratches, mechanical defects, or stochastic local discontinuities is broken down [5-8]. Ralston et al. [9] reviewed the literature about the corrosion of materials subjected to SPD, asserting that some investigations suggest a decrease of corrosion resistance for UFG aluminium alloys, particularly if processed by ECAP. This is related to the reduction of size of secondary-phase or intermetallic particles, which could operate as local cathodes or sites for the initiation of localized attack [10-12]. However, the morphology of nobler precipitates (size and 
distribution) influences the micro-scale electrochemical polarization, and consequently the corrosion behaviour of aluminium alloys [13,14].

The SPD of materials can be developed through the equal-channel angular pressing (ECAP) method [15]. In the recent years, ECAP has played an important role in comparing deformed materials with traditional coarse materials, because of its many advantages. The ECAP processes for Al alloys are significantly interesting in the automotive, aerospace, and building industries. Exceptional mechanical [15-21] and electrochemical properties [21-27] are observed in $\mathrm{Al}$ alloys because of ECAP.

Equal-channel angular pressing (ECAP) is the most significant and attractive method by which the materials are extruded without any change in the cross-section, by subjecting them to very large shear strain. The processing method of ECAP includes pressing a billet by using a die consisting of two channels of equal cross-section, intersecting at a specified angle $(\Phi)$. A very high shear strain is imposed on the material while it passes through the shear zone of the die [28-30]. After passing through the die, the billet exhibits no change in the cross-sectional area after the ECAP process; thus, it can be squeezed further for an additional number of passes. The distortion course can be shifted between the subsequent numbers of passes by turning the billets each time by $0^{\circ}$ (route $\mathrm{A}$ ), $90^{\circ}$ rotation of the sample (route $\left.B_{A}\right), 90^{\circ}$ in the same heading (route $B_{C}$ ), and $180^{\circ}$ rotation (route $C$ ) [16]. The amount of strain imposed and the desired microstructural changes in the ECAP processed material can be varied by picking the suitable channel angle $(\Phi)$, deformation route (as discussed above), and subjecting the material to the desired number of pressings [16,31-35]. A broad examination on the ECAP process has been performed for several decades to process various engineering materials deemed to be used in applications that demand high strength [36-44]. For these engineering materials, the mechanical and wear properties are given more importance, and the ECAP process forms a significant strategy for preparing materials with improved properties [35-39].

In this study, a financially accessible aluminum alloy (i.e., A15083) is exposed to ECAP processing through route $C$ to enhance its strength. Further examinations are performed to deal with the microstructural analysis and measurement of the electrochemical properties of the as-received and ECAP alloys.

\section{Experimental Procedure}

\subsection{ECAP Process of the Al5083 Alloy}

The samples were squeezed at ambient temperature for one to three passes by utilizing a hydraulic press with a maximum load capacity of 200 tons. The squeezing (pressing) speed was $0.6 \mathrm{~mm} / \mathrm{s}$. Route $\mathrm{C}$ was selected as the processing route (Figure 1) for the ECAP processing of the materials. The ECAP processing route selection was based on the reported literature, indicating that ECAP through route $C$ leads to a uniform plastic strain distribution in the processed material [45].

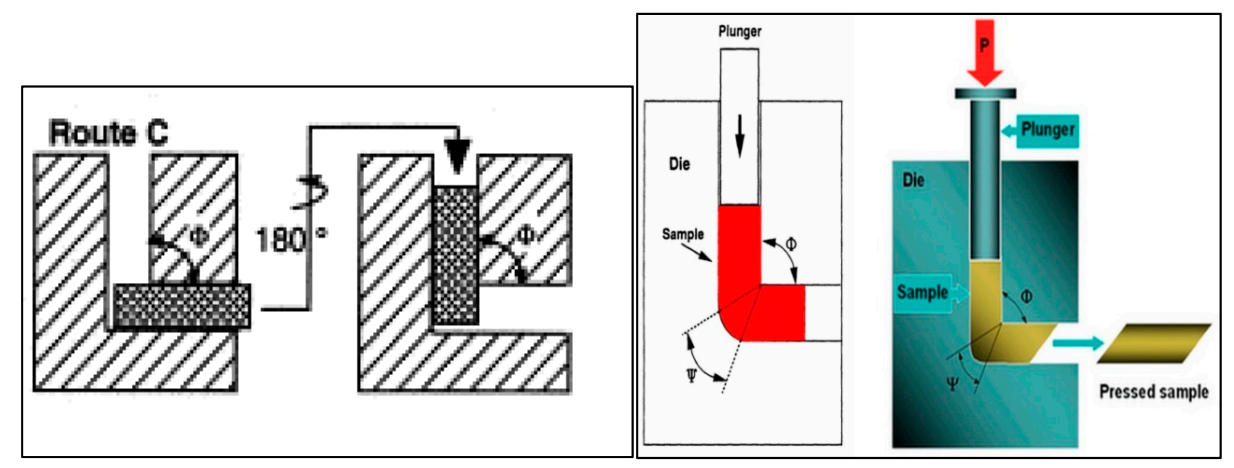

(A)

(B)

Figure 1. A schematic diagram of equal-channel angular pressing (ECAP) die: (A) route C path, (B) three-dimensional (3D) presentation of ECAP die. 


\subsection{Optical Microstructure}

Different grades of silicon carbide emery papers (e.g., 180, 120, 1/0, 2/0, etc.) were used to polish the samples. The samples were also cloth-polished using abrasives like alumina powder. After polishing, the samples were cleaned using an ultrasonic cleaner. To observe the microstructure, the samples were etched in ideal conditions using Keller's ( $2 \mathrm{~mL} \mathrm{HF}(40 \%)+3 \mathrm{~mL} \mathrm{HCl}(32 \%)+5 \mathrm{~mL} \mathrm{HNO}_{3}(65 \%)+$ $190 \mathrm{~mL} \mathrm{H}_{2} \mathrm{O}$ ) reagent [46]. A microstructural analysis of the samples was performed to examine them under a Leica optical microscope.

\subsection{Corrosion Test}

Specimens from the ECAP samples were used to study the corrosion properties. Each specimen was metallographically polished. The polished specimens were further tested to obtain their corrosive properties, using potentiodynamic polarization and electrochemical impedance spectroscopy (EIS) in $3.5 \%$ $\mathrm{NaCl}$ solution, using a potentiostat. The required chemical solutions were prepared using commercial $\mathrm{NaCl}$ with distilled water. Note that before proceeding with the genuine potentiodynamic tests, the open-circuit potential test was performed using the abovementioned test solution for $60 \mathrm{~min}$ to achieve a consistent state. Subsequently, a potentiodynamic examination was performed. These tests were completed by utilizing an ordinary three-cathode cell with a graphite bar and a saturated calomel anode (SCE). In these experiments, a polished sample was used as a working electrode; graphite was used as a counter electrode; and an SCE was used as a reference electrode. The polarization curves were generated at the interval from -1000 to $+1200 \mathrm{mV} \mathrm{SCE}$ at a constant scan rate of $1 \mathrm{mV} / \mathrm{s}$. Electrochemical impedance spectroscopy was executed over a wide frequency range of $100 \mathrm{kHz}$ to $0.01 \mathrm{~Hz}$.

\subsection{Raman Spectroscopy}

Raman spectroscopy was performed using a Jobin Yvon (Laboratory RAM HR800) confocal micro-Raman spectrometer. Raman spectroscopy was done to know the variation of surface chemical composition due to ECAP passes. Spectrometer backscattered geometry was employed through a $10 \times$ (NA $=0.25$ ) microscope objective. An $\mathrm{Ar}^{+}$laser with $514.5 \mathrm{~nm}$ wavelength was used as the excitation source. The amount of grating in the Raman spectrometer was 1800 grooves $/ \mathrm{mm}$. The Raman band of a silicon wafer at $520 \mathrm{~cm}^{-1}$ was used to align the spectrometer. All Raman spectra were recorded and gathered in the 200 to $1000 \mathrm{~cm}^{-1}$ range by utilizing three points of each sample in the reproducible tests.

\subsection{SEM Analysis}

A scanning electron microscope (SEM) was utilized to consider the surface morphology of the as-received and equal-channel, angularly pressed A15083 alloy. All studies were performed in the JEOL JSM-6360 model, and 200× magnification was used. Figure 2a-d depict SEM images.
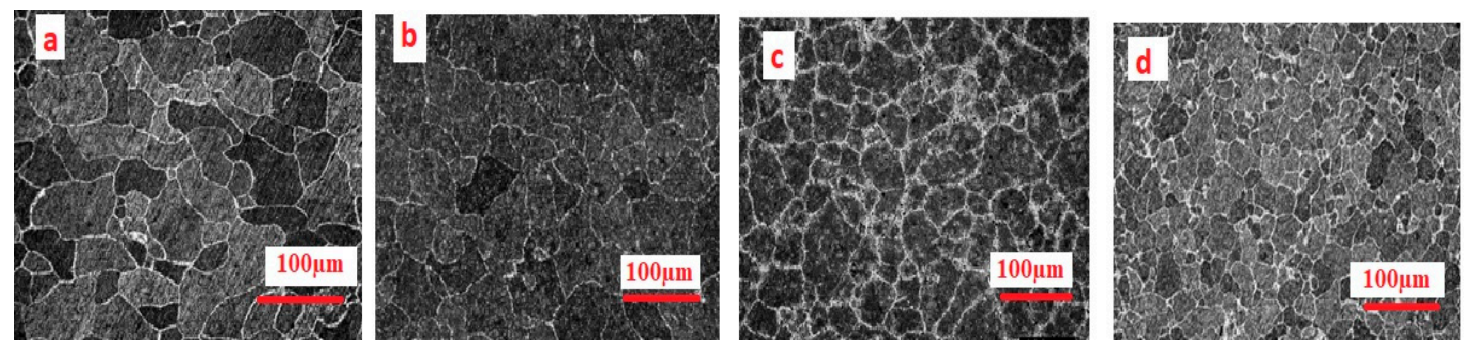

Figure 2. Al5083 alloy microstructure: (a) annealed; ECAP after the (b) first, (c) second, and (d) third passes. 


\section{Results and Discussion}

\subsection{Microstructure and Grain Size Analysis}

The following Figure 3 depicts the microstructure of the as-received and ECAP Al5083 samples. The as-received alloy had a coarse grain structure. The microstructures demonstrated that microscopically homogeneous, fine-grained structures were formed at a high deformation degree. The grain size was measured using Image J software. The as-received sample had a grain size of $145 \mu \mathrm{M}$, which decreased to $102 \mu \mathrm{M}$ after the first pass, $65 \mu \mathrm{M}$ after the second pass, and $37 \mu \mathrm{M}$ after the third pass. The grain refinement occurred due to the deformation produced by the ECAP.

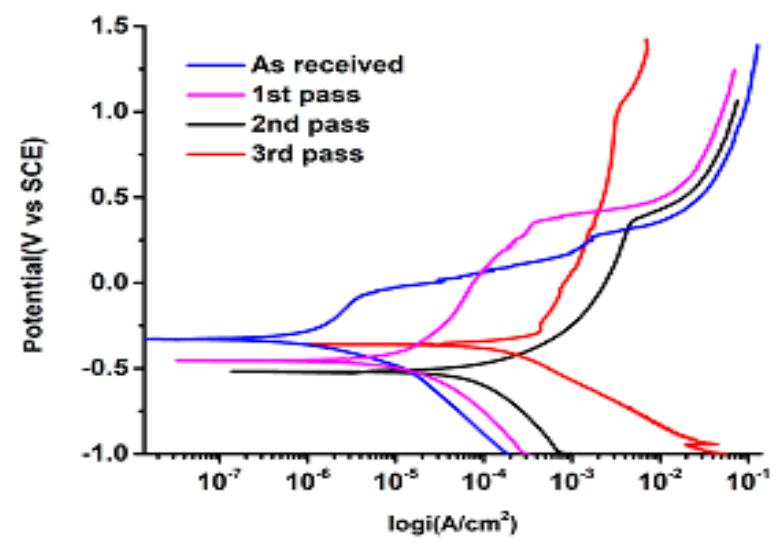

Figure 3. Potentiodynamic polarization curve of the $\mathrm{Al} 5083$ alloy in the $3.5 \% \mathrm{NaCl}$ solution.

A decrease in the grain sizes in the cross-section and an increase in the longitudinal section were observed. Figure $2 \mathrm{a}-\mathrm{d}$ illustrate the elongation and the refinement grains in the tested samples. A decrease in the grain size was primarily seen after the first pass through the channel, due to the original grains of the sample separating into subgrain groups.

On account of the multi-pass ECAP, the dislocation augmentation speed for the first pass was much bigger than that of the dislocation obliteration because of the little dislocation density. The material grains along these lines can be essentially refined. The grain refinement process went on as further passes occurred, because of the expansion of the internal energy and the dislocation density. The internal energy expansion caused the crystalline recovery and the recrystallization formation, such that the grain refinement was diminished step by step after a few passes. The grain refinement development procedure of the specimen was again changed for the diverse pressing routes. The accumulation and the equalization of the dislocations were likewise unique for Route $C$. The investigation of the deformation and the dislocation advancement might very well show that the materials with a nanostructure can be acquired by the ECAP process. The grain refinement procedure can be portrayed as consistently unique recuperation and recrystallization. From the viewpoint of a microstructure examination, the grain refinement procedure aims to control the dynamic evening out of the age and the demolition of the dislocations [47].

\subsection{Electrochemical Behavior}

When aluminum comes into contact with water, a protective layer of $\mathrm{AlOOH}$ forms on its surface [48]; however, when this passive layer comes into contact with chloride ions, anodic disintegration items (i.e., $\mathrm{AlOHCl}$ and $\mathrm{AlOHCl}_{2}$ ) develop. These products have a tendency to dissolve in water, thereby promoting the anodic disintegration of the passive film [49]. Figure 3 shows the polarization curve of the as-received Al5083 and ECAP samples in the $3.5 \% \mathrm{NaCl}$ solution. Table 1 presents the data obtained from these curves using Tafel's extrapolation method. 
Table 1. Potentiodynamic polarization results in the $3.5 \% \mathrm{NaCl}$ Solution.

\begin{tabular}{ccc}
\hline Sample & $\boldsymbol{i}_{\text {corr }}\left(\mathbf{A} / \mathbf{c m}^{\mathbf{2}}\right)$ & $\boldsymbol{E}_{\text {corr }}(\mathrm{V})$ \\
\hline Annealed & $1 \times 10^{-6}$ & $-3.29 \times 10^{-1}$ \\
First pass & $2 \times 10^{-5}$ & $-4.55 \times 10^{-1}$ \\
Second pass & $1 \times 10^{-4}$ & $-5.18 \times 10^{-1}$ \\
Third pass & $3 \times 10^{-4}$ & $-3.59 \times 10^{-1}$ \\
\hline
\end{tabular}

The curve and the data clearly show that the corrosion resistance property $\left(i_{\text {corr }}\right.$ value) increases with the increasing passes in the ECAP, compared to the as-received sample. No particular pattern was observed in the case of the corrosion potential ( $E_{\text {corr }}$ value). The as-received sample showed the highest $E_{\text {corr }}$ value compared to the ECAP sample, which can be explained by the micrograph given in Figure 2a-d. The grain refinement of this alloy increased after every pass. When grain refinement occurs, it provides more sites to initiate the corrosion (i.e., increases the corrosion rate, which decreases the overall corrosion resistance property). Grain refinement provides more areas for corrosion in two ways: (1) inside the grain boundary and (2) at the grain boundary. The results clearly indicate that with more ECAP passes comes the tendency of corrosion rate increase in the $\mathrm{Al}$ alloy, due to grain refinement [50].

Figures 4 and 5 represent the Bode magnitude and the Bode phase plot, respectively, in the $3.5 \%$ $\mathrm{NaCl}$ solution. The Bode magnitude plot exhibits two separate areas. In the lower- and higher-frequency sections, the Bode magnitude plot illustrates constant $\log |Z|$ values vs. $\log (f)$, indicating a response to the solution resistance. In the broad $(0.1-1000.0 \mathrm{~Hz})$ middle-frequency range, the spectra displayed a linear slope of approximately -1 . This is a characteristic response of the capacitive behavior of the surface film.

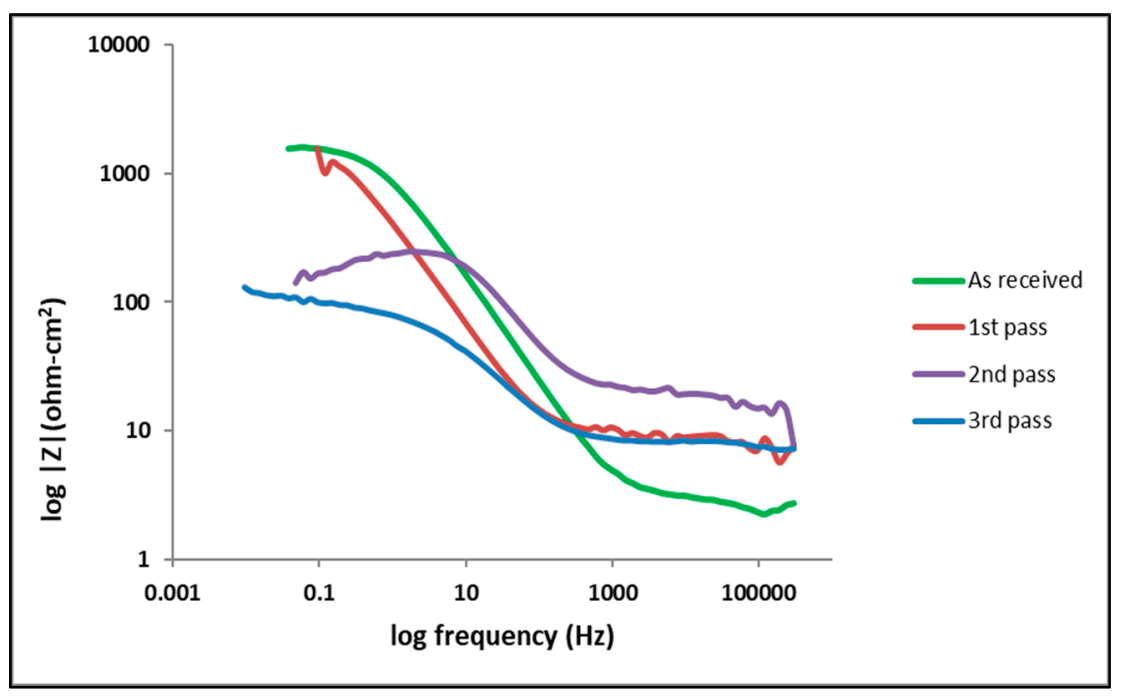

Figure 4. Electrochemical impedance spectroscope (EIS) log $|\mathrm{Z}|$ curve of the Al5083 alloy in 3.5\% $\mathrm{NaCl}$ solution.

The phase angle of the as-received sample approached $70^{\circ}$ in the Bode phase plot at the intermediate frequency range. For the other samples (first, second, and third passes), the phase angle gradually decreased to near $30^{\circ}$, showing a diffusion on the surface that affected the solution resistance and consequently lowered the corrosion resistance.

The character of all the Nyquist plots (Figure 6) exhibits almost the same pattern for all the samples. Hence, we may very well presume that the ECAP does not impact the surface character. The Nyquist plots demonstrated two different time constants: (1) one at high frequencies related to a well-defined loop, which can be ascribed to the parallel combination of polarize resistance $\left(R_{p}\right)$ 
and a double-layer constant phase element $\left(Q_{d l}\right)$; and (2) another at low frequencies related to a very dissipated loop, and in some cases, all around a characterized inductive loop.

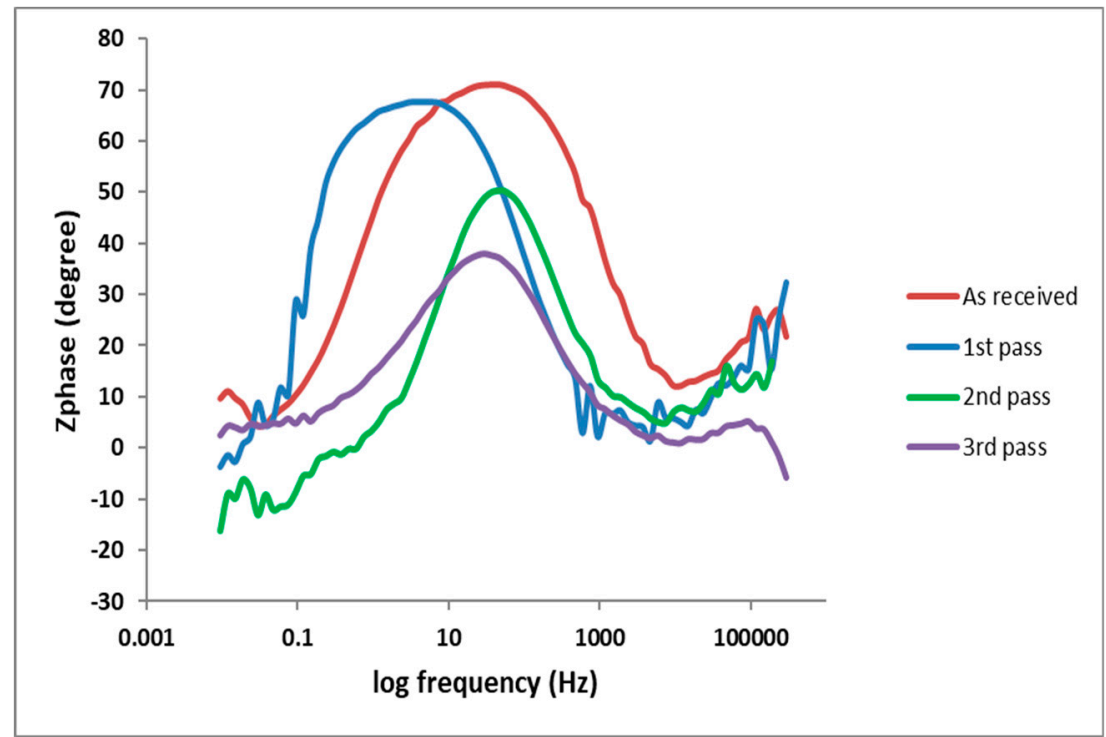

Figure 5. EIS Bode angle plot of the Al5083 alloy in the $3.5 \% \mathrm{NaCl}$ solution.

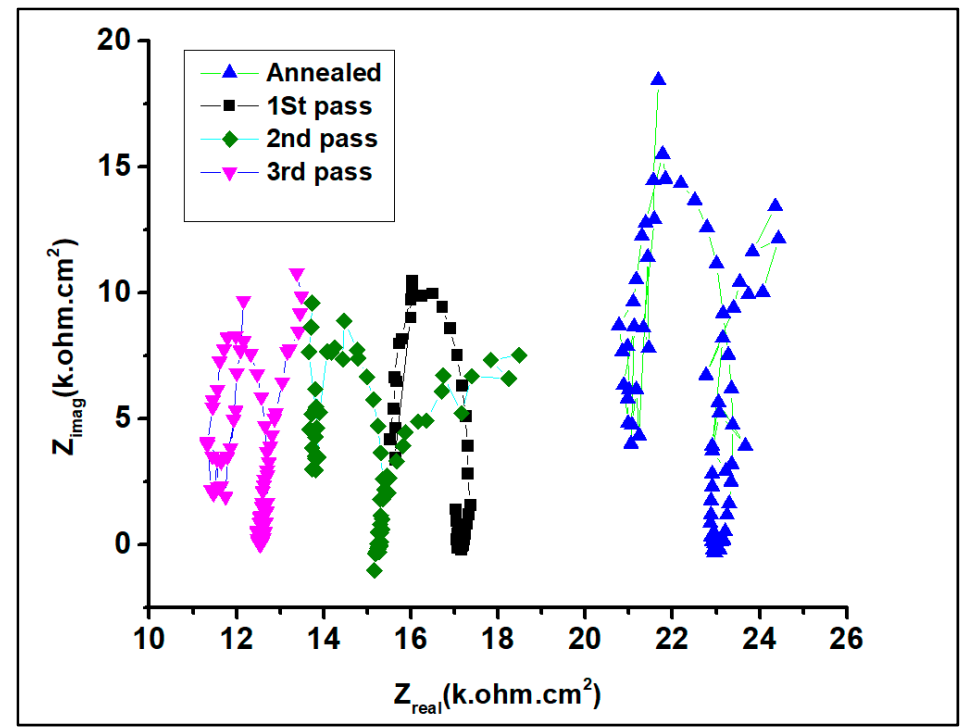

Figure 6. Nyquist plot curve of the $\mathrm{Al} 5083$ alloy in the $3.5 \% \mathrm{NaCl}$ solution.

The EIS of these samples was performed in the same $\mathrm{NaCl}$ solution. The influence of the grain refinement on the corrosion resistance was also found herein, supporting the above discussions [51]. The parameters obtained from the equivalent circuit were $R_{s}, R_{c t}, C P E, L$, and $R_{L}$, which symbolize the solution resistance, charge transfer resistance, constant phase element, inductance element, and electrical inductance, respectively. A capacitive loop was formed between the high-frequency and intermediate-frequency regions (HF/IF), while an inductive loop was formed between the intermediateand low-frequency (IF/LF) regions, as shown in the Nyquist plot for both the as-received and ECAP conditions. The charge transfer resistance $\left(R_{c t}\right)$ and the formation of a double-layer capacitance $\left(C_{d l}\right)$ at the $\mathrm{Al}$ alloy surface, as well as the interface of the solution, relied upon the capacitive region in HF/IF. The corrosion product formation, adsorption, and desorption on the metal surface depended on the inductive loop [52-56]. The initial stage of the pitting corrosion is indicated by $R_{L}$ and $L[57,58]$. 
The polarization resistance $\left(R_{P}^{-1}=R_{c t}{ }^{-1}+R_{L}{ }^{-1}\right)$ of the $\mathrm{Al}$ alloy was inversely proportional to the corrosion resistance. The corrosion resistance of the as-received sample was higher than that of the ECAP one, which was supported by the Nyquist plots, where the radius of the largest loop curve was observed for the as-received sample.

Table 2 presents the obtained $R_{p}$ values from these curves, and from the fitted circuit model (Figure 7). The Nyquist plot pattern was almost similar for the as-received and ECAP samples (Figure 6). Therefore, the ECAP may be expected to have very little effect on the character of the surface properties during corrosion. However, the microstructural state affected polarization resistance. After the ECAP processing, the polarization resistance value became lower than that in the as-received sample. A higher value of $R_{P}$ was found in the as-received sample compared to the ECAP sample under different passes. As referenced, a few papers have portrayed corrosion resistance variations as a function of the grain size caused by the expanded forced strain due to the ECAP. The $R_{p}$ value also supports the same herein.

Table 2. Electrochemical impedance spectroscopy results in the $3.5 \% \mathrm{NaCl}$ Solution.

\begin{tabular}{ccccccc}
\hline Sample & $\boldsymbol{R}_{\boldsymbol{S}}\left(\boldsymbol{\Omega} \mathbf{c m}^{\mathbf{2}}\right)$ & $\begin{array}{c}C P E \\
\left(\mu \mathrm{F} \cdot \mathbf{C m}^{-2} \cdot \mathbf{S}(\mathbf{n}-\mathbf{1})\right.\end{array}$ & $n$ & $\boldsymbol{R}_{c t}\left(\boldsymbol{\Omega} \mathbf{c m}^{2}\right)$ & $\boldsymbol{R}_{\mathbf{L}}\left(\boldsymbol{\Omega} \mathbf{c m}^{2}\right)$ & $\boldsymbol{L}\left(\mathbf{H ~ c m}^{-2}\right)$ \\
\hline As-received & 24.67 & 29.4 & 0.95 & $23.67 \times 10^{2}$ & 2127 & 1873 \\
First pass & 20.74 & 33.3 & 0.90 & $20.84 \times 10^{2}$ & 448 & 365 \\
Second pass & 23.44 & 48.6 & 0.85 & $19.44 \times 10^{2}$ & 302 & 213 \\
Third pass & 22.96 & 50.4 & 0.80 & $15.46 \times 10^{2}$ & 182 & 115 \\
\hline
\end{tabular}

Note: $R_{s}, R_{c t}, C P E, L, n$ and $R_{L}$, which symbolize the solution resistance, charge transfer resistance, constant phase element, inductance element, parameter measures the perfection of this element (varying between 0 and 1 ) and electrical inductance, respectively.

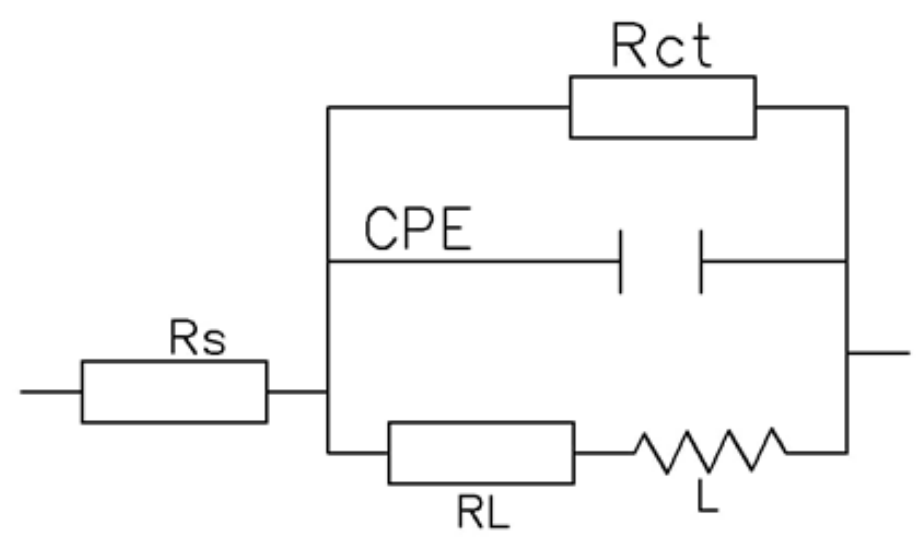

Figure 7. Equivalent potential circuit for the fitted model.

\subsection{Raman Spectroscopy Analysis}

Bayerite $\left(\alpha-\mathrm{Al}(\mathrm{OH})_{3}\right)$ with characteristic Raman bands (Figure 8 ) at 137,196 , and $321 \mathrm{~cm}^{-1}$ were detected from all zones of the ECAP Al5083 alloy immersed in the $3.5 \% \mathrm{NaCl}$ solution. On the contrary, only a weak Raman signal of $\alpha-\mathrm{Al}(\mathrm{OH})_{3}$ at $659 \mathrm{~cm}^{-1}$ was detected in the as-received sample immersed in the same solution. The nonappearance of noticeable Raman bands of $\mathrm{Al}(\mathrm{OH})_{3}$ in the as-received samples submerged in the solution is likely a sign of fewer corrosion products on these samples when compared with the ECAP samples [59].

\subsection{SEM Study}

SEM assessments were performed after the potentiodynamic polarization of the annealed and ECAP samples in the $3.5 \mathrm{wt} \% \mathrm{NaCl}$ solution. Figure 9 shows SEM micrographs indicating evidently limited degradation due to corrosion, especially on the three passes of the ECAP sample test. Figure 9a displays moderately little, semi-circular pits of various dimensions developed all through the non-deformed material surface. The number of pitting attacks increased due to the ECAP process. 
A much bigger and profound rectangular pit occurred after three passes. This attack happened in the interface between the particles and the Al lattice. In the current work, the tendency to be attacked by corrosion resulted from the neighboring galvanic cells framed between the $\alpha$-phase particles and the aluminium lattice. The particles present in the phase acted as cathodes herein. These acting cathodes allowed the decrease of oxygen and drove the anodic crumbling of the incorporating framework. The ECAP passed force to isolate these particles (Figure 9); therefore, the amount of the galvanic cells increased when the ECAP test was performed.

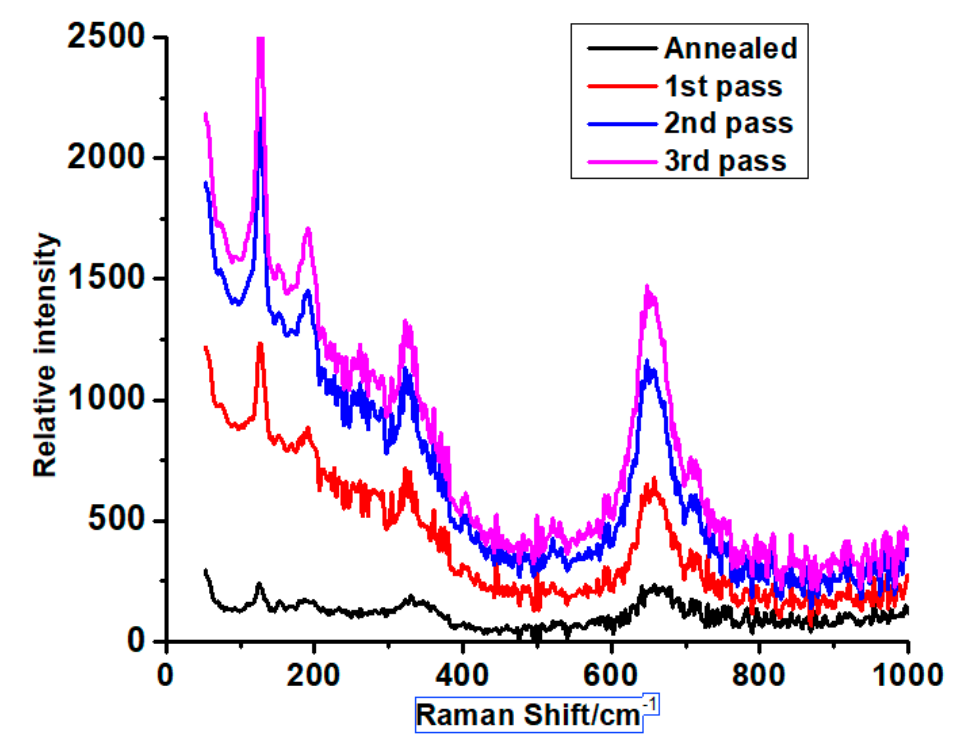

Figure 8. Raman spectroscopy plot of the as-received 5083 alloy in different solutions.
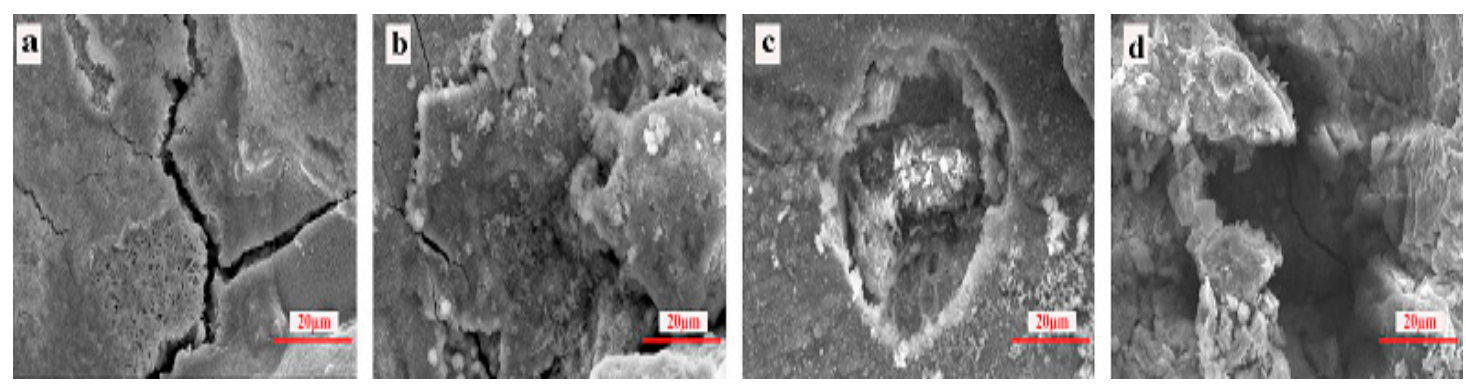

Figure 9. Scanning electron microscope (SEM) micrographs of the corroded surface of the 5083 alloy in $3.5 \% \mathrm{NaCl}$ solution of the (a) annealed samples, as well as the ECAP samples after the (b) first, (c) second, and (d) third passes.

\section{Conclusions}

In this study, the corrosion resistance of the ECAP samples showed a contrary effect compared to the as-received sample, due to the grain refinement observed from the first to third passes. The corrosion rate of the ECAP sample increased due to the grain refinement, which created more sites for initiating corrosion and subsequently decreased corrosion resistance. The absence of the prominent Raman bands of $\mathrm{Al}(\mathrm{OH})_{3}$ from the as-received samples was likely an indication of fewer corrosion products on these samples compared to the ECAP samples. The SEM micrographs also supported the same. The material surface degraded with increasing passes due to the decrease in the corrosion resistance property.

Author Contributions: Conceptualization, A.H.S., M.B. and A.U.R.; data curation, A.H.S., M.B. and A.U.R.; formal analysis, A.H.S., M.B. and A.U.R.; funding acquisition, A.H.S.; investigation, A.H.S. and M.B.; methodology A.H.S., M.B. and A.U.R.; resources, A.H.S.; supervision, A.H.S., M.B. and A.U.R.; writing—original draft, A.H.S., 
M.B. and A.U.R.; writing-review and editing, A.H.S., M.B. and A.U.R. All authors have read and agreed to the published version of the manuscript.

Funding: This project was supported by the National Science, Technology and Innovation Plan (NSTIP) Strategic Technologies Program (grant number 12-ADV3109-02), Kingdom of Saudi Arabia.

Acknowledgments: This project was supported by the NSTIP Strategic Technologies Program, grant number (12-ADV3109-02), Kingdom of Saudi Arabia.

Conflicts of Interest: The authors declare no conflict of interest.

\section{References}

1. Lin, Y.C.; Li, L.T.; Xia, Y.C.; Jiang, Y.Q. Hot deformation and processing map of a typical Al-Zn-Mg-Cu alloy. J. Alloys Compd. 2013, 550, 438-445. [CrossRef]

2. Maximov, J.T.; Duncheva, G.V.; Anchev, A.P. A new 3D finite element model of the spherical mandrelling process. Finite Elem. Anal. Des. 2014, 45,1-14. [CrossRef]

3. Zhou, M.; Lin, Y.C.; Deng, J.; Jiang, Y.Q. Hot tensile deformation behaviors and constitutive model of an Al-Zn-Mg-Cu alloy. Mater. Des. 2014, 59, 141-150. [CrossRef]

4. $\quad$ Li, L.T.; Lin, Y.C.; Zhou, H.M.; Xia, Y.C.; Jiang, Y.Q. Modeling the high-temperature creep behaviors of 7075 and 2124 aluminum alloys by continuum damage mechanics model. Comput. Mater. Sci. 2013, 73, $72-78$. [CrossRef]

5. Birbilis, N.; Muster, T.H.; Buchheit, R.G. Corrosion of Aluminum Alloys. In Corrosion Mechanism in Theory and Practice; Marcus, P., Ed.; CRC Press: New York, NY, USA, 2012; pp. 705-736. ISBN 9781420094626.

6. Frankel, G.S. Pitting Corrosion of Metals. J. Electrochem. Soc. 1998, 145, 2186. [CrossRef]

7. Chen, G.S.; Gao, M.; Wei, R.P. Microconstituent-Induced Pitting Corrosion in Aluminum Alloy 2024-T3. Corrosion 1996, 52, 8-15. [CrossRef]

8. Ly, R.; Hartwig, K.T.; Castaneda, H. Effects of strain localization on the corrosion behavior of ultra-fine grained aluminum alloy AA6061. Corros. Sci. 2018, 139, 47-57. [CrossRef]

9. Ralston, K.D.; Birbilis, N. Effect of Grain Size on Corrosion: A Review. Corrosion 2010, 66. [CrossRef]

10. Yulinova, A.; Nickel, D.; Frint, P.; Lampke, T. Electrochemical Properties of AL-6060 Alloy After Industrial-Scale ECAP. Mater. Sci. 2012, 48, 191-196. [CrossRef]

11. Sikora, E.; Wei, X.J.; Shaw, B.A. Corrosion Behavior of Nanocrystalline Bulk Al-Mg-Based Alloys. Corrosion 2004, 60, 387-398. [CrossRef]

12. Son, I.J.; Nakano, H.; Oue, S.; Kobayashi, S.; Fukushima, H.; Horita, Z. Pitting corrosion resistance of anodized aluminum-copper alloy processed by severe plastic deformation. Nippon Kinzoku Gakkaishi/J. Jpn. Inst. Met. 2008, 72, 353-359. [CrossRef]

13. Hockauf, M.; Meyer, L.W.; Nickel, D.; Alisch, G.; Lampke, T.; Wielage, B.; Krüger, L. Mechanical properties and corrosion behavior of ultrafine-grained AA6082 produced by equal-channel angular pressing. J. Mater. Sci. 2008, 43, 7409-7417. [CrossRef]

14. Son, I.-J.; Nakano, H.; Oue, S.; Kobayashi, S.; Fukushima, H.; Horita, Z. Pitting Corrosion Resistance of Anodized Aluminum Alloy Processed by Severe Plastic Deformation. Mater. Trans. 2007, 48, 21-28. [CrossRef]

15. Segal, V.M.; Reznikov, V.I.; Drobyshevskiy, A.E.; Kopylov, V.I. Plastic working of metals by simple shear. Russ. Metall. 1981, 1, 99-105.

16. Valiev, R.Z.; Langdon, T.G. Principles of equal-channel angular pressing as a processing tool for grain refinement. Progr. Mater. Sci. 2006, 51, 881-981. [CrossRef]

17. El-Danaf, E.A. Mechanical properties and microstructure evolution of 1050 aluminum severely deformed by ECAP to 16 passes. Mater. Sci. Eng. A 2008, 487, 189-200. [CrossRef]

18. Hockauf, M.; Meyer, L.W.; Zillmann, B.; Hietschold, M.; Schulze, S.; Krüger, L. Simultaneous improvement of strength and ductility of $\mathrm{Al}-\mathrm{Mg}-\mathrm{Si}$ alloys by combining equal-channel angular extrusion with subsequent high-temperature short-time aging. Mater. Sci. Eng. A 2009, 503, 167-171. [CrossRef]

19. Frint, P.; Halle, T.; Wagner, M.F.X.; Hockauf, M.; Lampke, T. Scaling up the equal-channel angular pressing process-A study on a 6000 aluminium alloy. Mat. Sci. Eng. Tech. 2010, 41, 814-821. 
20. Frint, P.; Hockauf, M.; Halle, T.; Strehl, G.; Lampke, T.; Wagner, M.F.X. Microstructural features and mechanical properties after industrial scale ECAP of an Al-6060 alloy. Mater. Sci. Forum 2011, 667-669, 1153-1158. [CrossRef]

21. Viceré, A.; Roventi, G.; Paoletti, C.; Cabibbo, M.; Bellezze, T. Corrosion Behavior of AA6012 Aluminum Alloy Processed by ECAP and Cryogenic Treatment. Metals 2019, 9, 408. [CrossRef]

22. Son, I.J.; Nakano, H.; Oue, S.; Kobayashi, S.; Fukushima, H.; Horita, Z. Effect of equal-channel angular pressing on pitting corrosion resistance of anodized aluminium copper alloy. Trans. Nonferr. Met. Soc. China 2009, 19, 904-908. [CrossRef]

23. Chung, M.K.; Choi, Y.S.; Kim, J.G.; Kim, Y.; Lee, J. Effect of the number of ECAP pass time on the electrochemical properties of $1050 \mathrm{Al}$ alloys. Mater. Sci. Eng. A 2004, 366, 282-291. [CrossRef]

24. Jiang, J.H.; Ma, A.B.; Lu, F.M.; Saito, N.; Watazu, A.; Song, D.; Zhang, P.; Nishida, Y. Improving corrosion resistance of Al-11 mass.\% Si alloy through a large number of ECAP passes. Mater. Corr. 2011, 62, 848-852. [CrossRef]

25. Dan, S.; Jiang, J.H.; Lin, P.H.; Yang, D.H. Corrosion behavior of ultrafine-grained industrial pure Al fabricated by ECAP. Trans. Nonferr. Met. Soc. China 2011, 19, 1065-1070.

26. Akiyama, E.; Zhang, Z.; Watanabe, Y.; Tsuzaki, K. Effects of severe plastic deformation on the corrosion behavior of aluminium alloys. J. Solid State Electrochem. 2009, 13, 277-282. [CrossRef]

27. Brunner, J.G.; Birbilis, N.; Ralston, K.D.; Virtanen, S. Impact of ultrafine-grained microstructure on the corrosion of aluminium alloy AA2024. Corr. Sci 2012, 57, 209-2014. [CrossRef]

28. Segal, V.M. Materials processing by simple shear. Mater. Sci. Eng. 1995, 197, 157-164. [CrossRef]

29. Valiev, R.Z. Structure and mechanical properties of ultrafine-grained metals. Mater. Sci. Eng. A 1997, 234-236,59-66. [CrossRef]

30. Valiev, R.Z.; Korznikov, A.V.; Mulyukov, R.R. Structure and properties of ultrafine-grained materials produced by severe plastic deformation. Mater. Sci. Eng. 1993, 168, 141-148. [CrossRef]

31. Sun, P.L.; Kao, P.W.; Chang, C.P. Effect of deformation route on microstructural development in aluminum processed by equal channel angular extrusion, met. Mater. Trans. A 2004, 35, 1359-1368. [CrossRef]

32. Bi, J.; Sun, K.; Liu, R.; Fan, R.; Wang, S. Effect of ECAP pass number on mechanical properties of $2 \mathrm{~A} 12$ al alloy. J. Wuhan Univ. Technol. Mat. Sci. Edit. 2008, 23, 71-73. [CrossRef]

33. Gao, L.; Cheng, X. Microstructure and mechanical properties of $\mathrm{Cu}-10 \% \mathrm{Al}-4 \%$ Fe alloy produced by equal channel angular extrusion. Mater. Des. 2008, 29, 904-908. [CrossRef]

34. Khan, Z.A.; Chakkingal, U.; Venugopal, P. Analysis of forming loads, microstructure development and mechanical property evolution during equal channel angular extrusion of a commercial grade aluminum alloy. J. Mater. Process. Technol. 2003, 135, 59-67. [CrossRef]

35. Kucukomeroglu, T. Effect of equal-channel angular extrusion on mechanical and wear properties of eutectic Al-12Si alloy. Mater. Des. 2010, 31, 782-789. [CrossRef]

36. Gao, L.L.; Cheng, X.H. Microstructure and dry sliding wear behavior of $\mathrm{Cu} 10 \% \mathrm{Al}-4 \% \mathrm{Fe}$ alloy produced by equal channel angular extrusion. Wear 2008, 265, 986-991. [CrossRef]

37. Jiang, J.; Wang, Y.; Du, Z.; Qu, J.; Sun, Y.; Luo, S. Enhancing room temperature mechanical properties of Mg-9Al-Zn alloy by multipass equal channel angular extrusion. J. Mater. Process. Technol. 2010, 210, 751-758. [CrossRef]

38. Mallikarjuna, C.; Shashidhara, S.M.; Mallik, U.S. Evaluation of grain refinement and variation in mechanical properties of equalchannel angular pressed 2014 aluminum alloy. Mater. Des. 2009, 30, 1638-1642. [CrossRef]

39. Ramu, G.; Bauri, R. Effect of equal channel angular pressing (ECAP) on microstructure and properties of Al-SiCp composites. Mater. Des. 2009, 30, 3554-3559. [CrossRef]

40. Tham, Y.W.; Fu, M.W.; Hng, H.H.; Yong, M.S.; Lim, K.B. Bulk nanostructured processing of aluminum alloy. J. Mater. Process. Technol. 2007, 192-193, 575-581. [CrossRef]

41. Pürçek, G. Improvement of mechanical properties for $\mathrm{Zn}-\mathrm{Al}$ alloys using equal-channel angular pressing. J. Mater. Process. Technol. 2005, 169, 242-248. [CrossRef]

42. Saray, O.; Purcek, G. Microstructural evolution and mechanical properties of Al-40 wt.\%Zn alloy processed by equal-channel angular extrusion. J. Mater. Process. Technol. 2009, 209, 2488-2498. [CrossRef]

43. Tolaminejad, B.; Dehghani, K. Microstructural characterization and mechanical properties of nanostructured AA1070 aluminum after equal channel angular extrusion. Mater. Des. 2012, 34, 285-292. [CrossRef] 
44. Adedoku, S.T. A review on equal channel angular extrusion as a deformation and grain refinement process. J. Emerg. Trends Eng. Appl. Sci. (JETEAS) 2011, 2, 360-363.

45. Javidikia, M.; Hashemi, R. Mechanical anisotropy in ultra-fine grained aluminium tubes processed by parallel-tubular-channel angular pressing. Mater. Sci. Technol. 2017, 33, 2265-2273. [CrossRef]

46. Mohammadtaheri, M. A new metallographic technique for revealing grain boundaries in aluminum alloys. Metallogr. Microstruct. Anal. 2012, 1, 224-226. [CrossRef]

47. Chung, Y.H.; Park, J.W.; Lee, K.H. An analysis of accumulated deformation in the equal channel angular pressing (ECAP) process. Met. Mater. Int. 2006, 12, 289-292. [CrossRef]

48. Gorman, J.D.; Hughes, A.E.; Jamieson, D.; Paterson, P.J.K. Oxide formation on aluminum alloys in boiling deionised water and $\mathrm{NaCl}, \mathrm{CeCl} 3$ and $\mathrm{CrCl} 3$ solutions. Corros. Sci. 2003, 45, 1103-1124. [CrossRef]

49. Szklarska-Smialowska, Z. Pitting corrosion of aluminum. Corros. Sci. 1999, 41, 1743-1767. [CrossRef]

50. Lee, J.-C.; Seok, H.-K.; Suh, J.-Y. Microstructural evolutions of the Al strip prepared by ECAP and continuous equal channel angular pressing electrochemical behaviour. Acta Materialia 2002, 50, 4005-4019. [CrossRef]

51. Nam, C.Y.; Han, J.H.; Chung, Y.H.; Shin, M.C. Effect of precipitates on microstructural evolution of $7050 \mathrm{Al}$ alloy sheet during equal channel angular pressing effect in corrosion. Mater. Sci. Eng. A 2003, 347, 253-257. [CrossRef]

52. Kubásek, J.; Dvorský, D.; Čavojský, M.; Vojtěch, D.; Beronská, N.; Fousová, M. Superior properties of Mg-4Y-3RE-Zr alloy prepared by powder metallurgy. J. Mater. Sci. Technol. 2017, 33, 652-660. [CrossRef]

53. Shuzhen, Z.; Lining, X.; Juanjuan, D.; Wei, C.; Minxu, L. Influence of acetic acid on top localized corrosion of x70 steel pipeline in $\mathrm{CO}_{2}$ containing wet gas. J. Chin. Soc. Corros. Prot. 2016, 36, 231-237.

54. Farelas, F.; Ramirez, A. Carbon dioxide corrosion inhibition of carbon steels Through bis-imidazoline and imidazoline compounds studied by EIS. Int. J. Electrochem. Sci. 2010, 5, 797-814.

55. Seikh, A.H.; Baig, M.; Ammar, H.R.; Alam, M.A. The influence of transition metals addition on the corrosion resistance of nanocrystalline al alloys produced by mechanical alloying. Metals 2016, 6, 140. [CrossRef]

56. Khadiri, A.; Ousslim, A.; Bekkouche, K.; Aouniti, A.; Elidrissi, A.; Hammouti, B. Phenolic and non-phenolic Fractions of the Olive Oil Mill Wastewaters as Corrosion Inhibitor for steel in $\mathrm{HCl}$ medium. Port. Electrochim. Acta 2014, 32, 35-50. [CrossRef]

57. Wu, J.; Xue, W.; Wang, B.; Jin, X.; Du, J.; Li, Y. Characterization of carburized layer on T8 steel fabricated by cathodic plasma electrolysis. Surf. Coat. Technol. 2014, 245, 9-15. [CrossRef]

58. Guo, X.; Guo, Q.; Du, K.; Wang, Y.; Wang, F. Study of filiform corrosion inhibition by a compact plasma electrolytic oxidation film on a AZ31 Mg alloy. RSC Adv. 2016, 6, 39053-39062. [CrossRef]

59. Teymoory, P.; Zarei-Hanzaki, A.; Farabi, E.; Monajati, H.; Abedi, H.R. Grain refinement through ECAP in severely plastic deformed A206 aluminum alloy. Adv. Eng. Mater. 2018, 20, 1700502. [CrossRef]

Publisher's Note: MDPI stays neutral with regard to jurisdictional claims in published maps and institutional affiliations.

(C) 2020 by the authors. Licensee MDPI, Basel, Switzerland. This article is an open access article distributed under the terms and conditions of the Creative Commons Attribution (CC BY) license (http://creativecommons.org/licenses/by/4.0/). 